\title{
Cold-stress-induced de novo expression of infC and role of IF3 in cold-shock translational bias
}

\author{
ANNA MARIA GIULIODORI, ANNA BRANDI, MARA GIANGROSSI, CLAUDIO O. GUALERZI, \\ and CYNTHIA L. PON \\ Laboratory of Genetics, Department of Biology MCA, University of Camerino, 62032 Camerino (MC), Italy
}

\begin{abstract}
Expression of Escherichia coli infC, which encodes translation initiation factor IF3 and belongs to a transcriptional unit containing several promoters and terminators, is enhanced after cold shock, causing a transient increase of the IF3/ribosomes ratio. Here we show that after cold shock the two less used promoters $\left(P_{T}\right.$ and $\left.P_{11}\right)$ remain active and/or are activated, resulting in de novo infC transcription and IF3 synthesis. These two events are partly responsible for the stoichiometric imbalance of the IF3/ribosomes ratio that contributes to establishing the cold-shock translational bias whereby cold-shock mRNAs are preferentially translated by cold-stressed cells while bulk mRNAs are discriminated against. Analysis of the IF3 functions at low temperature sheds light on the molecular mechanism by which IF3 contributes to the cold-shock translational bias. IF3 was found to cause a strong rate increase of fMet-tRNA binding to ribosomes programmed with cold-shock mRNA, an activity essential for the rapid formation of "30S initiation complexes" at low temperature. The increased IF3/ribosome ratio occurring during cold adaptation was also essential to overcome the higher stability of 705 monomers at low temperature so as to provide a sufficient pool of dissociated $30 \mathrm{~S}$ subunits capable of "70S initiation complex" formation. Finally, at low temperature IF3 was shown to be endowed with the capacity of discriminating against translation of non-cold-shock mRNAs by a cold-shock-specific "fidelity" function operating with a mechanism different from those previously described, insofar as IF3 does not interfere with formation of $30 \mathrm{~S}$ initiation complex containing these mRNAs, but induces the formation of nonproductive $70 \mathrm{~S}$ initiation complexes.
\end{abstract}

Keywords: cold stress; ribosome dissociation; transcriptional control; translational bias; translation initiation

\section{INTRODUCTION}

Cold-shock translational bias, namely, the condition that favors translation at low temperature of cold-shock mRNAs, is one of the main and most characteristic mechanisms by which the cell ensures the selective expression of its cold-shock genes (Brandi et al. 1996; Goldenberg et al. 1997; Giuliodori et al. 2004). Translational bias occurs during the 3-5 $\mathrm{h}$ (depending upon the temperature) acclimation phase, which begins after the cold stress and ends when the cells resume slow growth at low temperature. The bias is due to cis elements contained in the coldshock mRNAs that make them more prone to translation at low temperature and to trans elements associated with the translational apparatus of the cold-shocked cells.

Reprint requests to: Claudio O. Gualerzi, Laboratory of Genetics, Department of Biology MCA, University of Camerino, 62032 Camerino (MC), Italy; e-mail: Claudio.gualerzi@unicam.it; fax: 390737636216.

Article published online ahead of print. Article and publication date are at http://www.rnajournal.org/cgi/doi/10.1261/rna.455607.
Bacteria require three protein factors (IF1, IF2, and IF3) to initiate protein synthesis, a key event that can determine fidelity, efficiency, and regulation of gene expression. In the cell the levels of these factors (IFs) are kept always constant with respect to the ribosomes, whose level varies depending upon cellular growth rate (Howe and Hershey 1983; Liveris et al. 1991). However, after cold stress, the level of the IFs increases in the absence of a corresponding increase of the number of ribosomes, thereby creating an exceptional imbalance in the IFs/ribosome ratio. This seems to be at least one of the causes of the above mentioned cold shock translational bias (Giuliodori et al. 2004).

Although several hypotheses can be formulated concerning the mechanism that generates this imbalance, information that could lead to the correct explanation is still missing. In particular, it is necessary to know whether the relative increase of the amount of factors compared to that of ribosomes is due to the synthesis of new IF molecules occurring after the cold stress and, if this is the case, whether this synthesis is directed by preexisting mRNA 
made more stable by the cold shock, by newly transcribed mRNAs, or both.

Genetic experiments have shown that IF3 is necessary for cell survival (Olsson et al. 1996) indicating that one or more of its numerous activities (for review, see Gualerzi et al. 2001; Boelens and Gualerzi 2002; Laursen et al. 2005) is essential, even under optimal conditions of growth. Furthermore, IF3, together with IF1, was shown to play a fundamental role in determining the translational bias during cold acclimation (Giuliodori et al. 2004), but nothing is known of the molecular mechanism(s) of this activity.

Thus, the present work was focused on the identification of the mechanism responsible for the increased expression of IF3 during cold shock and on unraveling the molecular basis of the IF3-dependent translation bias. To identify the $\operatorname{step}(\mathrm{s})$ of the translational pathway, which depend upon the increased level of IF3 during cold adaptation, we analyzed the individual initiation steps at high and at low temperature using the transcripts of two paralogous genes ( $\operatorname{csp} A$ and $\operatorname{csp} D$ ) that are produced and translated by the cells in response to different environmental cues (Goldstein et al. 1990; Yamanaka and Inouye 1997; Brandi et al. 1999; Giangrossi et al. 2001) as a paradigm "cold-shock" and "non-cold-shock" mRNA, respectively.

The results obtained indicate that after cold shock the infC gene is transcribed de novo, primarily from two of its less used (at $37^{\circ} \mathrm{C}$ ) promoters and is actively translated up to at least $4 \mathrm{~h}$ after the temperature downshift. The present study has also identified three translational steps that are critically influenced by IF3 at low temperature, namely, the formation of the $30 \mathrm{~S}$ initiation complex, of the $70 \mathrm{~S}$ initiation complex, and the maintenance of favorable subunit association/dissociation equilibrium. The latter two steps were also found to require the increased IF3/ribosomes ratio.

Finally, the present study provides evidence that IF3 discriminates against translation in the cold of non-cold-shock mRNA. Although superficially similar to other known cases in which IF3 behaves as a fidelity factor during translation initiation, this IF3 function occurs through a novel mechanism, different from that used by the factor to discriminate against translation of templates which form nonstandard 30S initiation complexes (for review, see Gualerzi et al. 2001).

\section{RESULTS}

\section{Levels of infC mRNAs before and after cold shock}

In Escherichia coli, infC is found in a cluster of genes encoding components of the translational apparatus such as thrS (threonyl tRNA synthetase), rpmI and rplT (ribosomal proteins L35 and L20, respectively), and pheS and pheT (the small and large subunit of phenylalanyl tRNA synthetase) (GrunbergManago 1996). Several promoters and transcriptional terminators have been identified within the cluster so that, at least in theory, several transcripts encoding IF3 could be present in the cell (Fig. 1; Wertheimer et al. 1988; Lesage et al. 1990; Liveris et al. 1991; Grunberg-Manago 1996). To analyze the cold-shock induction of infC expression, E. coli cells in early and late exponential phase of growth at $37^{\circ} \mathrm{C}$ were stressed by an abrupt temperature shift from $37^{\circ} \mathrm{C}$ to $10^{\circ} \mathrm{C}$ and the steady-state levels of the total infCmRNA determined as a function of the time after the stress. As seen from the results in Figure 2A, the level of infCmRNA increases steadily after the stress, reaching its maximum within the first $2-3 \mathrm{~h}$ of cold adaptation. Similar to that observed with other cold-shock-induced genes like $\operatorname{csp} A$ and infA (Brandi et al. 1999; Giangrossi et al. 2007), also in the case of infC, the cold shock increase of the IF3 mRNA level is larger in cells stressed in late exponential phase, which contain a lower basal level of this RNA, than in those stressed in early exponential growth, which contain a higher level of IF3 mRNA.

To identify the promoter(s) responsible for the increased level of the infC transcript, total RNA extracted from coldshocked cells was preliminarily subjected to electrophoretic separation to detect and quantify, on the basis of their size and published data (Wertheimer et al. 1988; Liveris et al. 1991), the levels of the individual infC transcripts as a function of the time elapsed from the onset of the stress (Fig. 2B,C). As seen from Figure 2, B and C, in the preshock controls, the level of the transcripts originating from the

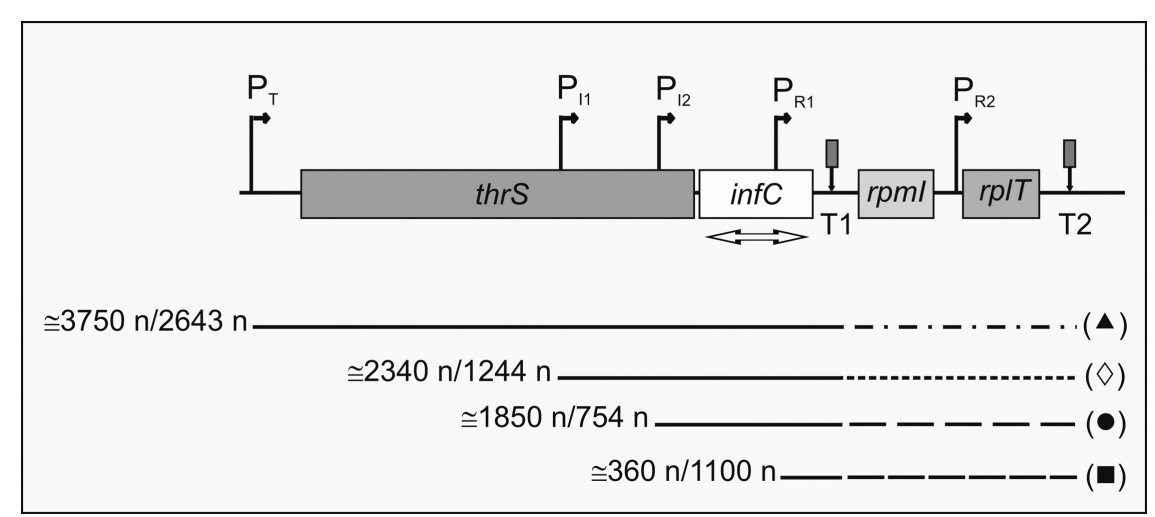

FIGURE 1. Gene organization of the E. coli infC operon. Schematic representation of the chromosomal gene organization near the $E$. coli infC operon. The genes and their distances are in scale. The location of the natural transcription promoters $\left(\mathrm{P}_{T}, \mathrm{P}_{I 1}, \mathrm{P}_{\mathrm{I} 2}, \mathrm{P}_{\mathrm{R} 1}\right.$, and $\left.\mathrm{P}_{\mathrm{R} 2}\right)$ and terminators (T1 and T2) are indicated. The approximate lengths of the transcripts, detectable with our probe, originating from $(\boldsymbol{\Delta}) \mathrm{P}_{\mathrm{T}},(\diamond) \mathrm{P}_{\mathrm{I} 1},(\bullet) \mathrm{P}_{\mathrm{I} 2}$, and $(\boldsymbol{\square}) \mathrm{P}_{\mathrm{R} 1}$ and terminating at $\mathrm{T} 1$ or $\mathrm{T} 2$ are indicated by the numbers to the left of the lines below the diagram. The transcriptional signals present in the gene cluster have been independently identified by two groups (Wertheimer et al. 1988; Lesage et al. 1990; Liveris et al. 1991). The notation used here is according to Liveris et al. (1991). 

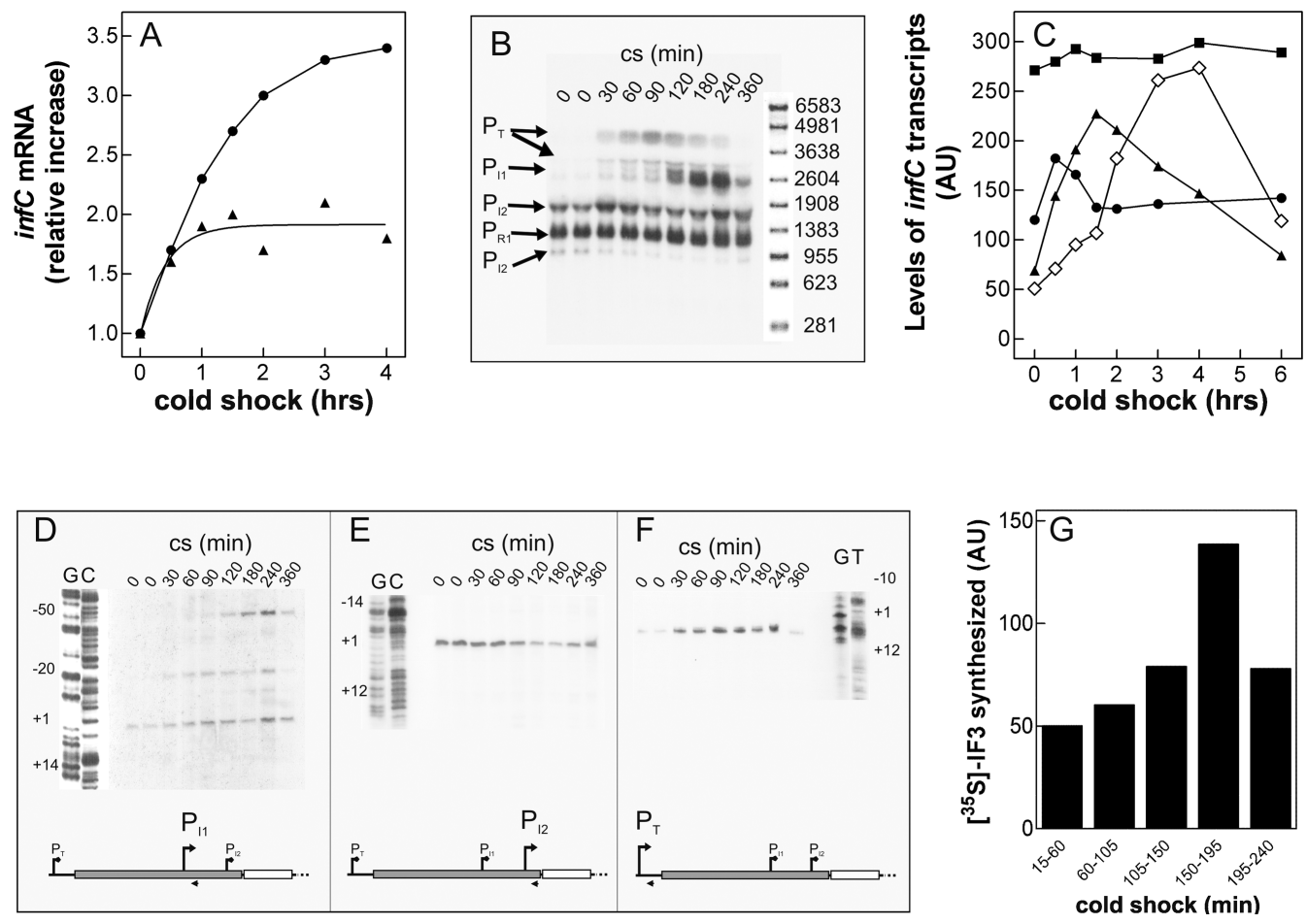

FIGURE 2. Steady-state levels of infCmRNAs and de novo synthesis of IF3 during cold adaptation. (A) Cellular steady-state levels of total infCmRNA as a function of the time elapsed after cold shock (downshift to $10^{\circ} \mathrm{C}$ ) induced in $E$. coli MRE600 cultures having reached $\mathrm{A}_{600}=0.3$ $(\boldsymbol{\Delta})$ and $\mathrm{A}_{600}=1.2(\bullet)$ upon growth in $\mathrm{LB}$ at $37^{\circ} \mathrm{C}$. The measured steady-state level at $37^{\circ} \mathrm{C}$ of infCmRNA in cells in the early exponential phase was between 1.4- and 1.5-fold higher than in cells in late exponential phase. The Northern blots were hybridized with a radioactive infC DNA probe (indicated by the double-headed arrow in Fig. 1) and quantified by molecular imaging. $(B)$ Autoradiography of the Northern blot of the electrophoretically resolved infC transcripts present in the total RNA extracted at the indicated times after cold shock $\left(10^{\circ} \mathrm{C}\right)$ from $E$. coli MRE600 cells stressed upon reaching $\mathrm{A}_{600}=1.2$ at $37^{\circ} \mathrm{C}$ in $\mathrm{LB}$. The individual transcripts were identified according to their size, estimated by reference to an RNA molecular weight ladder (Sigma) run in parallel, and confirmed by primer extension analysis. (C) Variation, as a function of time of cold shock, of the steady-state levels of individual infC transcripts $(\boldsymbol{\Delta}) \mathrm{P}_{\mathrm{T}},(\diamond) \mathrm{P}_{\mathrm{I} 1},(\bullet) \mathrm{P}_{\mathrm{I} 2}$, and $(\boldsymbol{\square}) \mathrm{P}_{\mathrm{R} 1}$ quantified by Molecular Imager and expressed as arbitrary units $(\mathrm{AU}) .(D-F)$ Primer extension analysis of the $\mathrm{P}_{\mathrm{I} 1}(D), \mathrm{P}_{\mathrm{I} 2}(E)$, and $\mathrm{P}_{\mathrm{T}}(F)$ infC transcripts present in the total RNA purified from E. coli cells subjected to cold shock for the indicated times upon reaching $\mathrm{A}_{600}=1.2$ at $37^{\circ} \mathrm{C}$ in $\mathrm{LB}$. The numbering to the left of each autoradiograph is given according to translational start sites identified by Wertheimer et al. (1988). The scheme below each panel represents the position of the primer (arrow head) used for the identification of the respective transcript, with respect to thrS (light gray rectangle) and infC (dark gray rectangle). Further details are given in Materials and Methods. $(G)$ De novo synthesis of IF3 following cold shock was studied by pulse labeling for $45 \mathrm{~min}$ at $10^{\circ} \mathrm{C}$ as described in Materials and Methods. After immunoprecipitation and electrophoretic separation, the radioactivity was quantified on the dried gel by Molecular Imager. The height of each histogram bar represents the radioactivity, expressed in arbitrary units (AU), incorporated into IF3 during the indicated labeling times. Further details are given in Materials and Methods.

various promoters is quite different. Aside from the abundant transcript originating from $\mathrm{P}_{\mathrm{R} 1}$, which contains only part of the coding region of infC, there is a detectable amount of the transcript originating from $\mathrm{P}_{\mathrm{I} 2}$, while those originating from $\mathrm{P}_{\mathrm{T}}$ and $\mathrm{P}_{\mathrm{I} 1}$ are barely visible; however, while the level of the $\mathrm{P}_{\mathrm{R} 1}$ and $\mathrm{P}_{\mathrm{I} 2}$ transcripts does not significantly change after the stress, the levels of those originating from $\mathrm{P}_{\mathrm{T}}$ and from $\mathrm{P}_{\mathrm{I}}$ increase substantially within the first $4 \mathrm{~h}$ following cold shock.

The above identification of the infC transcripts synthesized during cold shock was fully confirmed by primer extension analysis carried out on the total RNA isolated, before and after cold shock, from E. coli cells in the late exponential phase of growth (Fig. 2D-F). These experiments also confirmed that the level of the transcript originating from $\mathrm{P}_{\mathrm{I} 2}$ (Fig. 2E) remains substantially constant before and after the stress, while the levels of $\mathrm{P}_{\mathrm{I} 1}$ (Fig. 2D) and $\mathrm{P}_{\mathrm{T}}$ (Fig. 2F) transcripts are increased upon the temperature downshifts. Concerning the $\mathrm{P}_{\mathrm{I} 1}$ transcript, it can be seen from Figure 2D that, in addition to the RNA initiating precisely in the position expected from the published literature (Wertheimer et al. 1988), there are two additional bands, 20 and 50 bases longer than $P_{I 1}$ transcript, respectively. While also the intensity of these bands increases with time of cold shock, it is not obvious if these are additional, upstream start points activated by the cold stress or specific cleavage points of a transcript originating from an upstream promoter.

Finally, additional experiments were carried out in which rifampicin was given to the cells at the onset of cold stress. It was found that this transcriptional initiation inhibitor completely blocks the increase of the steady-state level of 
the infC transcripts (data not shown). This finding indicates that cold-shock induction of IF3 entails, among other things, de novo transcription of infC from two of its less frequently used promoters.

\section{De novo synthesis of IF3 after cold shock}

The presence of a transcript in a cell does not constitute per se evidence of its translational capacity. For this reason, to investigate whether de novo synthesis of IF3 indeed occurs after cold shock, aliquots of cell culture were pulse labeled with $\left[{ }^{35} \mathrm{~S}\right]-\mathrm{Met} / \mathrm{Cys}$ at different times following the exposure to cold $\left(10^{\circ} \mathrm{C}\right)$; the labeled proteins were then immunoprecipitated with anti-IF3 antibodies, analyzed by PAGE/SDS electrophoresis, and subjected to autoradiography. The results obtained show that IF3 is actively translated de novo immediately after cold shock and that, although the maximum synthesis occurs $\sim 180$ min after the cold stress, synthesis continues even after 240 min (Fig. 2G).

\section{Cold-shock and non-cold-shock mRNA translation at low temperature}

The effect of IF3 in determining the cold-shock translational bias was studied comparing its effect on the activity of a typical "cold-shock" ( $\operatorname{csp} A m R N A)$ and a "non-coldshock" ( $\operatorname{csp} D \mathrm{mRNA}$ ) transcript. CspA and $\operatorname{csp} D$ belong to the large family of $\operatorname{csp}$ genes that, in $E$. coli, consists of nine members, only four of which $(\operatorname{csp} A, \operatorname{csp} B, \operatorname{csp} G$, and $\operatorname{csp} I)$ are preferentially expressed after cold shock (Yamanaka et al. 1998). CspA and $\operatorname{cspD}$ are monocistronic genes transcribed in two mRNAs of similar size that encode two proteins of almost identical size and $55 \%$ sequence identity. The transcript of $\operatorname{csp} A$ ( $\operatorname{csp} A \mathrm{mRNA})$ was selected as a paradigm cold-shock mRNA since it has been demonstrated that it is preferentially and efficiently transcribed and translated following cold shock (Gualerzi et al. 2003). On the other hand, the transcript of $\operatorname{csp} D$ ( $\operatorname{csp} D \mathrm{mRNA}$ ) was selected as a paradigm non-cold-shock mRNA because it is expressed during stationary phase and following glucose starvation (Yamanaka and Inouye 1997) but is poorly translated at low temperature (Giuliodori et al. 2004).

The time course of cspAmRNA (panel A) and cspDmRNA (panel B) translation in vitro at $37^{\circ} \mathrm{C}$ and $15^{\circ} \mathrm{C}$ by extracts of control (non-cold-shocked) and coldshocked cells is presented in Figure 3. The results indicate that $\operatorname{csp} A m R N A$ is translated much more efficiently than $\operatorname{cspDmRNA}$ at both high and low temperatures. However, whereas the level of protein synthesized with cspAmRNA as template is similar at $37^{\circ} \mathrm{C}$ and $15^{\circ} \mathrm{C}$, the efficiency of $\operatorname{csp} D$ mRNA translation at $37^{\circ} \mathrm{C}$ is much greater than at $15^{\circ} \mathrm{C}$, indicating that this mRNA is a poor template at low temperature. Finally, the results indicate that at $37^{\circ} \mathrm{C}$ the extract of cold shocked cells (normalized for their ribosomal content) is two times more efficient in translating

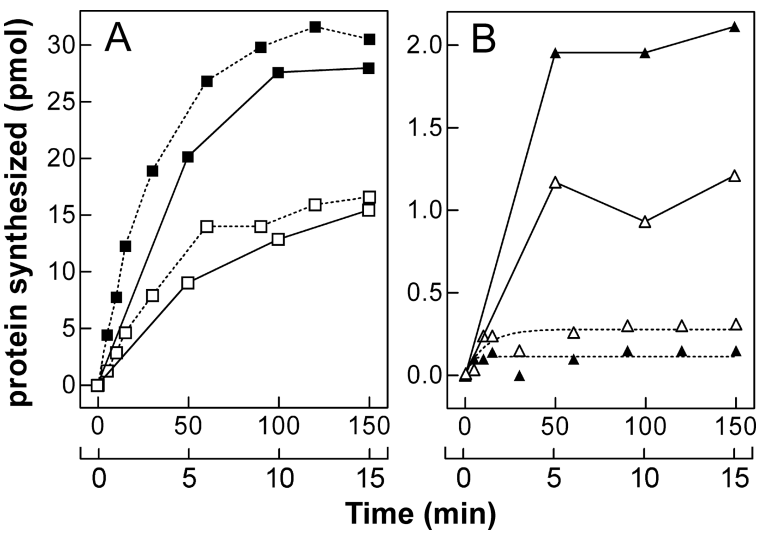

FIGURE 3. Time course of cold-shock and non-cold-shock mRNA translation at low and high temperature. Time course of $c s p A m R N A$ $(A)$ and $\operatorname{csp} D m R N A(B)$ translation carried out at $15^{\circ} \mathrm{C}$ (broken lines) and $37^{\circ} \mathrm{C}$ (continuous lines) in the presence of equivalent amounts of $E$. coli MRE600 S30 extracts prepared from cells harvested before (open symbols) and after 120 min cold shock (filled symbols) as described in Materials and Methods. Samples, withdrawn from each reaction mixture at the time intervals indicated for translation at $15^{\circ} \mathrm{C}$ (upper abscissa) and $37^{\circ} \mathrm{C}$ (lower abscissa), were subjected to hot TCA treatment to quantify the radioactive product synthesized. Further details are given in Materials and Methods.

both $\operatorname{csp} A m R N A$ and $c s p D m R N A$ than the extract of control cells. On the other hand, while cspAmRNA is translated more efficiently by the extract of cold-shocked cells at $15^{\circ} \mathrm{C}$ (positive translational bias), translation of $\operatorname{cspDmRNA}$ is inhibited at low temperature (negative translational bias) by the same extract (Fig. 3).

These findings confirm the presence, in the extracts of cold-shocked cells, of "cold-shock factors" which selectively favor the translation of cold-shock mRNAs at low temperature while discriminating against non-cold-shock mRNAs (Giuliodori et al. 2004).

The experiments presented in the following sections were designed to elucidate the role of IF3 in determining the cold-shock translational bias.

\section{Temperature-dependent influence of IF 3 on the formation of $30 \mathrm{~S}$ and $70 \mathrm{~S}$ initiation complexes}

Formation of $30 \mathrm{~S}$ and $70 \mathrm{~S}$ initiation complexes directed by $\operatorname{cspAmRNA}$ and $\operatorname{cspDmRNA}$ was studied as a function of increasing IF3 concentration at high and low temperature. In these experiments, either $30 \mathrm{~S}$ or a mixture of $30 \mathrm{~S}$ and 50 S ribosomal subunits were incubated with IF1, IF2, fMettRNA, and either $\operatorname{csp} A$ (Fig. 4A,B) or $\operatorname{cspD}$ (Fig. 4C,D) mRNA in the presence of increasing concentrations of IF3. As seen from these figures, IF3 determines a modest stimulation of 30SIC formation regardless of mRNA and temperature used (maximum stimulation is $35 \%$ and $50 \%$ at $37^{\circ} \mathrm{C}$ and $15^{\circ} \mathrm{C}$, respectively). It can also be noted from these experiments that stimulation reaches a plateau at IF3 concentrations lower than those of the 30 S subunits. 

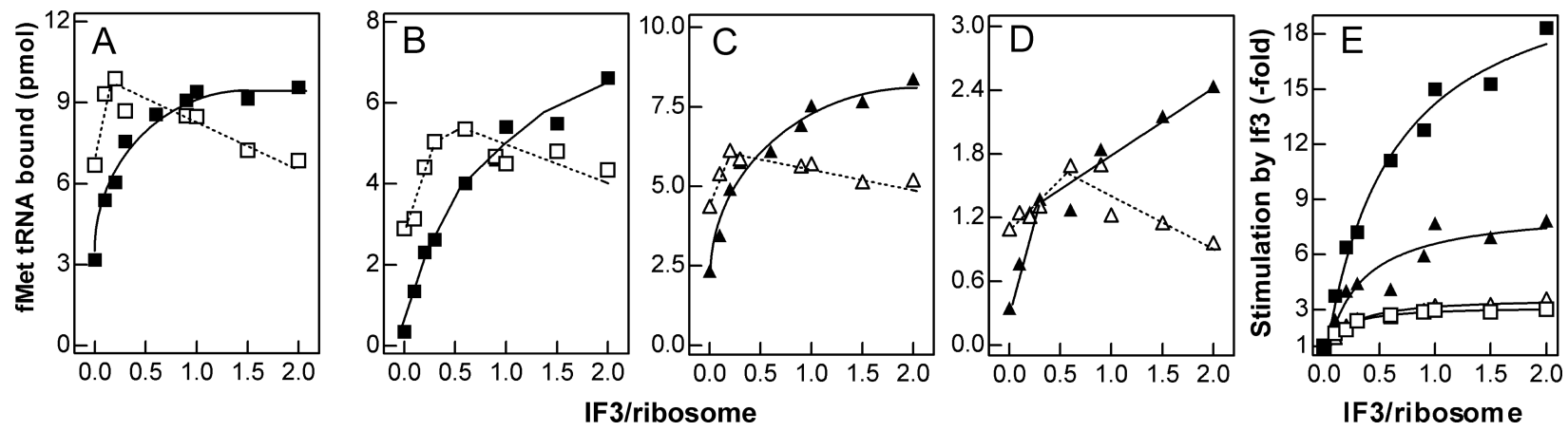

FIGURE 4. Effect of IF3 on the formation of $30 \mathrm{~S}$ and $70 \mathrm{~S}$ initiation complexes at low and high temperature. The reaction was performed at $37^{\circ} \mathrm{C}$ $(A, C)$ or $15^{\circ} \mathrm{C}(B, D)$ with $\operatorname{csp} A m R N A(\square, \mathbf{\square})$, or with $\operatorname{cspDmRNA}(\triangle, \mathbf{\Lambda})$ as a function of the increasing IF3/ribosome ratio indicated in the abscissa. In addition, each reaction mixture contained IF1, IF2, f[ $\left.{ }^{35} \mathrm{~S}\right]$ Met-tRNA, and $30 \mathrm{~S}$ ribosomal subunits $(\square, \triangle)$ or a mixture of stoichiometrically equivalent amounts of $30 \mathrm{~S}$ and $50 \mathrm{~S}$ subunits $(\mathbf{\square}, \mathbf{\Delta})$. After $30 \mathrm{~min}$ incubation at the indicated temperatures, the amount of $\mathrm{f}\left[{ }^{35} \mathrm{~S}\right]$ Met-tRNA bound in the $30 \mathrm{~S}$ initiation complex or $70 \mathrm{~S}$ initiation complex was determined by nitrocellulose disc filtration. (E) To visualize better the effect of IF3 on 70S initiation complex formation with $\operatorname{cspAmRNA}(\square, \boldsymbol{\square})$ and $\operatorname{csp} \operatorname{DmRNA}(\triangle, \boldsymbol{\Delta})$, at $37^{\circ} \mathrm{C}$ (open symbols) and $15^{\circ} \mathrm{C}$ (closed symbols), the ratio of the $\left[\left[^{35} \mathrm{~S}\right]\right.$ Met-tRNA bound in the presence and absence of IF3 (which is the measure of the stimulation due to IF3) is plotted as a function of increasing IF3/ribosome ratios. The amount of radioactivity remaining on the filters in the absence of mRNA was taken as representing the background and subtracted from each point. Further details are given in Materials and Methods.

Concerning the efficiency by which the two templates support 30SIC formation, it can be seen that, while at $37^{\circ} \mathrm{C}$ the amount of initiator tRNA bound to the $30 \mathrm{~S}$ subunit in response to $c s p A m R N A$ and $c s p D m R N A$ (Fig. 4, cf. panels A and C) is similar (9 vs. 5.5 pmol, respectively), a substantially larger difference is observed at $15^{\circ} \mathrm{C}$, since the amount of 30SIC formed is $\geq 3$ times higher with cspAmRNA than with cspDmRNA (6 versus 1.8 pmol) (Fig. 4B,D).

Unlike with 30SIC, 70SIC formation is stimulated strongly and selectively (for both template and temperature) by an excess of IF3. In fact, while at $37^{\circ} \mathrm{C}$ fMet-tRNA binding to $70 \mathrm{~S}$ is increased threefold regardless of the template, at $15^{\circ} \mathrm{C}$ IF3 causes a sevenfold and 18 -fold stimulation with $\operatorname{cspDmRNA}$ and $\operatorname{csp} A \mathrm{mRNA}$, respectively (Fig. 4E), the maximum stimulation requiring a greater than twofold stoichiometric excess of IF3 over the ribosomes. Furthermore, comparison of the results obtained under different binding conditions (Fig. 4A-D) shows that in the absence of IF3 the amount of fMet-tRNA bound to the $70 \mathrm{~S}$ ribosomes is always lower than the amount bound to the $30 \mathrm{~S}$. At $37^{\circ} \mathrm{C}$, these differences are modest (i.e., twofold) with both mRNAs, but at low temperature the differences are larger and depend upon the nature of the template, being 10 -fold and fourfold with cspAmRNA and with $\operatorname{cspDmRNA}$, respectively. However, these differences are progressively lost by increasing amounts of IF3, so that the ratio of 30S-bound versus 70S-bound fMet-tRNA becomes $\cong 1$ with $\operatorname{cspAmRNA}$, and $\leq 1$ with $\operatorname{cspDmRNA}$. Thus, taken together, these data indicate that fMet-tRNA binding to $70 \mathrm{~S}$ at low temperature displays an increased IF3 dependence, especially with the cold-shock mRNA.

Since it is known that the $30 S+50 S \leftrightarrows 70 S$ equilibrium is shifted to the right at low temperature (Zitomer and Flaks
1972), our findings suggest that one of the cold-shock functions of IF3 could be that of favoring the formation of a $70 \mathrm{~S}$ initiation complex by counteracting the low-temperature-induced subunit association, thereby providing a suitable pool of $30 \mathrm{~S}$ ribosomal subunits under the unfavorable cold-shock conditions. In fact, the absence of a sufficiently large pool of $30 \mathrm{~S}$ subunits when $30 \mathrm{~S}$ and $50 \mathrm{~S}$ subunits are incubated together in the cold in the absence of IF3 would explain the finding that under these conditions only a small amount of fMet-tRNA is ribosome bound (Fig. 4B,D). Furthermore, the fact that this IF3 activity is seen primarily with cold-shock mRNA suggests that an additional cold-shock function of IF3 could be that of favoring the correct decoding of a cold-shock mRNA recognized by virtue of some specific cis-acting structural feature. Acting together, these IF3 functions could provide a molecular basis for the IF3-dependent cold shock translational bias.

Direct evidence for the validity of these premises was sought in the experiments shown below.

\section{Kinetics of $30 \mathrm{~S}$ initiation complex formation with different templates as a function of temperature}

To clarify the reason for the selective stimulation of initiation complex formation at low temperature when the ribosome is programmed with the cold shock cspAmRNA, fMet-tRNA binding to $30 \mathrm{~S}$ subunits programmed with either cspAmRNA (Fig. 5A,C), or cspDmRNA (Fig. 5B,D) was analyzed by rapid filtration comparing the kinetics of binding obtained at $37^{\circ} \mathrm{C}$ (Fig. $\left.5 \mathrm{~A}, \mathrm{~B}\right)$ and $15^{\circ} \mathrm{C}$ (Fig. 5C,D) in the presence and absence of IF3. As seen in the Figures 5, A-D, depending upon temperature, nature of the template and presence or absence of IF3, these reactions differ for the 

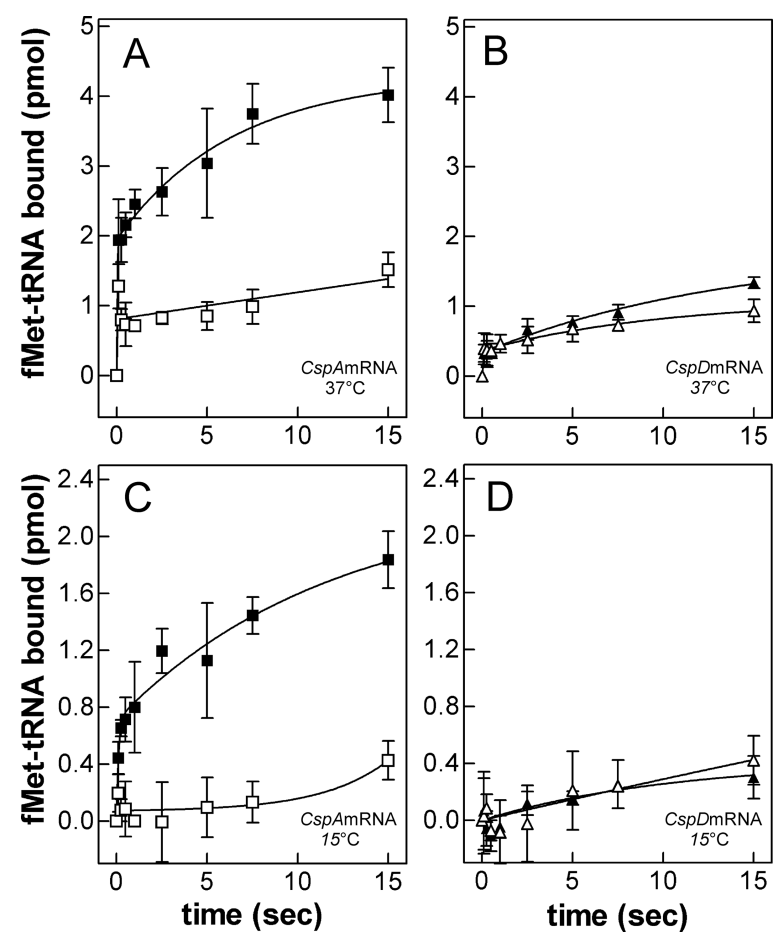

FIGURE 5. Effect of IF3 on the time course of 30 S initiation complex formation. The kinetics of fMet-tRNA binding to $30 \mathrm{~S}$ subunit in the presence $(\boldsymbol{\square}, \mathbf{\Lambda})$ and absence $(\square, \triangle)$ of IF3 was studied by rapid nitrocellulose filtration using a modified quench-flow apparatus. As described in Materials and Methods, the reaction was started by rapidly mixing two solutions, one containing GTP, 30S ribosomal subunits, and equimolar amounts of IF1, IF2, and IF3 (if present) while the other contained $\mathrm{f}\left[{ }^{35} \mathrm{~S}\right]$ Met-tRNA and either $\operatorname{csp} A(\boldsymbol{\square}, \square$, panels $A, C)$ or $\operatorname{csp} D$ mRNA $(\boldsymbol{\Delta}, \triangle$, panels $B, D)$. The concentrations of all ligands are indicated in Materials and Methods. After mixing, the reaction was allowed to proceed for the indicated times at $37^{\circ} \mathrm{C}(A, B)$ or $15^{\circ} \mathrm{C}(C, D)$, stopped by fast dilution and rapidly filtered through nitrocellulose discs to quantify the amount of 30S-bound $f\left[{ }^{35} \mathrm{~S}\right]$ MettRNA. The amount of radioactivity remaining on the filters in the absence of mRNA was taken as representing the background and subtracted from each point. The plotted values represent the average ( \pm standard deviation) of four experimental points.

velocity at which fMet-tRNA binding occurs and for the binding level that can be attained. In most of the cases binding takes place in two phases, a rapid one, which occurs in a burst within the initial $100 \mathrm{~ms}$, and a slower one, for which a $K_{\text {app }}$ can be determined. At $37^{\circ} \mathrm{C}$ and with cspAmRNA as template, IF3 produces only a slight increase of the rate of the reaction (i.e., from $k_{\text {app }}=0.06-0.03 \mathrm{sec}^{-1}$ ) and increases between two- and threefold the amount of 30S-bound initiator tRNA but has no effect on the binding reaction when the template is cspDmRNA.

At $15^{\circ} \mathrm{C}$, in the presence of IF3 and with $\operatorname{csp} A m R N A$ as template, the binding reaction proceeds with a similar $k_{\text {app }}$ $\left(0.1 \mathrm{sec}^{-1}\right)$ as at $37^{\circ} \mathrm{C}$, but the level of fMet-tRNA bound is reduced about $50 \%$. However, in the absence of IF3 the level of binding is drastically reduced and the kinetic behavior is different, with binding preceded by a rather long ( $\geq 7 \mathrm{sec}$ ) lag. Finally, with $\operatorname{cspDmRNA}$ as template, very little fMet-tRNA binding occurs and there is no obvious difference in the presence or absence of IF3.

In addition to the two above mentioned fMet-tRNA binding phases, a third, slow binding phase appears upon increasing the incubation time. This phase is $\sim 10$ times slower than the second one and, as a result, the level of $30 \mathrm{~S}$ initiation complex formed is essentially the same with and without IF3 if the incubation is allowed to proceed long enough (i.e., $\cong 5 \mathrm{~min}$ ).

Taken together, the above data indicate that IF3 stimulates 30S initiation complex formation only with the cold-shock mRNA and that its stimulation is larger at low temperature. It is therefore likely that this stimulation by IF3 is necessary to yield a sufficient level of 30SIC within a physiologically relevant timescale.

Results (not shown) almost identical to those presented above were also obtained when the experiments were carried out in the presence of a stoichiometric excess of IF3 similar to that generated in vivo by the cold stress. Thus, whereas the presence of IF3 seems strictly required to sustain cold-shock mRNA-dependent binding of fMettRNA at low temperature, a normal stoichiometry of this factor is sufficient to elicit this activity. Therefore, our results seem to rule out that the cold-shock-induced increase of the IF3 level is necessary to meet a more stringent need for the factor in stimulating $30 \mathrm{~S}$ initiation complex formation.

\section{Formation of fMet-puromycin as a function of temperature and mRNA template}

The above results have shown that the amount of initiation complex formed and its rate of formation depend upon temperature and type of mRNA. The experiments presented below were devised to determine whether the complexes formed with different mRNAs at different temperatures are productive as donor in the formation of the first peptide bond.

For this purpose, 50S subunits and puromycin were added to $30 \mathrm{~S}$ initiation complexes formed at $37^{\circ} \mathrm{C}$ or $15^{\circ} \mathrm{C}$ with either $\operatorname{csp} A \mathrm{mRNA}$ or $\operatorname{csp} D \mathrm{mRNA}$ and the amount of fMet-puromycin thereby produced determined.

The results of these experiments demonstrate that fMetpuromycin is formed rapidly with both mRNAs at both temperatures with saturation being reached within 5-10 sec (Fig. 6A). However, while the level of fMet-puromycin formed at $37^{\circ} \mathrm{C}$ (i.e., $\cong 70 \%-80 \%$ of ribosome-bound fMettRNA) is approximately the same with cold-shock and non-cold-shock mRNA, at $15^{\circ} \mathrm{C}$ the "initiation complex" formed with $\operatorname{csp} D \mathrm{mRNA}$ is mostly (75\%) nonproductive, unlike that formed with cspAmRNA, which is $\geq 85 \%$ productive (Fig. 6A).

A possible role of IF3 in determining the nonproductivity of the 30SIC formed at $15^{\circ} \mathrm{C}$ with $\operatorname{cspDmRNA}$ was 

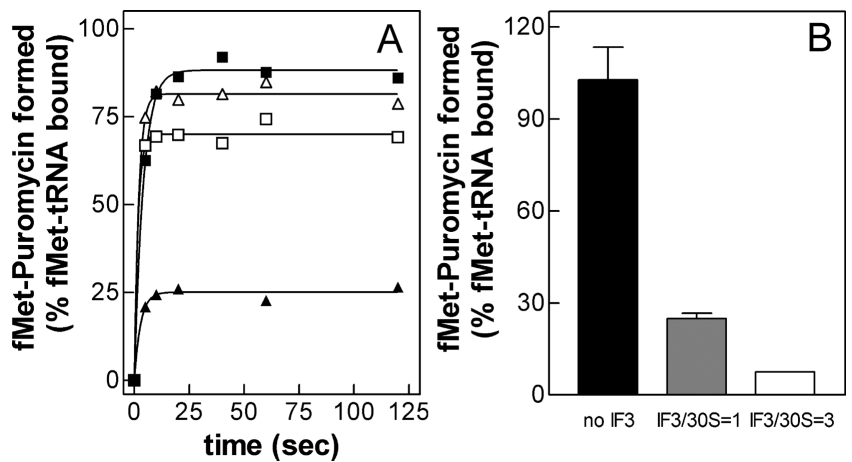

FIGURE 6. Template- and temperature-dependent effect of IF3 on the $\mathrm{f}\left[{ }^{35} \mathrm{~S}\right]$ Met-puromycin formation. (A) Time course of $\mathrm{f}\left[{ }^{35} \mathrm{~S}\right]$ Metpuromycin formation at $37^{\circ} \mathrm{C}(\triangle, \square)$ and $15^{\circ} \mathrm{C}(\boldsymbol{\Lambda}, \boldsymbol{\square})$ with $30 \mathrm{SIC}$ containing $\operatorname{cspAmRNA}(\square, \mathbf{\square})$ or $\operatorname{cspDmRNA}(\triangle, \mathbf{\Lambda})$. The 30SIC were prepared as described in Materials and Methods incubating at the indicated temperatures stoichiometric equivalents of $30 \mathrm{~S}$ subunits, IF1, IF2, IF3, f[ $\left.{ }^{35} \mathrm{~S}\right]$ Met-tRNA, and mRNA as specified. At the indicated times after the addition of a solution containing puromycin and $50 \mathrm{~S}$ subunits, samples were withdrawn and the amount of $\mathrm{f}\left[{ }^{35} \mathrm{~S}\right]$ Met-puromycin formed was determined after ethyl acetate extraction as described in Materials and Methods. (B) Effect of IF3 on the amount of fMet-puromycin formed in $30 \mathrm{sec}$ at $15^{\circ} \mathrm{C}$ with 30SIC containing cspDmRNA. IF3 was either absent (black bar) or present in a stoichiometric equivalence (1:1) (gray bar) or excess (3:1) (white bar) with respect to the $30 \mathrm{~S}$ subunits. Each bar represents the average ( \pm standard deviation) of three experimental points. The amount of $\mathrm{f}\left[{ }^{35} \mathrm{~S}\right]$ Met-puromycin formed in the absence of mRNA was taken as representing the background and subtracted from each point.

further analyzed preparing 30SIC in the absence of IF3 and in the presence of two different amounts of this factor. As seen in Figure 6B, fMet-puromycin is formed efficiently ( $\cong 100 \%$ of the bound fMet-tRNA) with 30SIC lacking IF3, while the efficiency of the reaction drops to $\cong 25 \%$ and to $<10 \%$ with 30 SIC containing IF3 at IF3/30S ratios $=1$ and 3 , respectively.

These data indicate that IF3 discriminates against the fMet-tRNA bound to the ribosomes at low temperature in response to a non-cold-shock mRNA, and it seems reasonable to assume that the structures of the 30S-cspDmRNA binary complex and/or of the ternary complex thereupon formed with fMet-tRNA are "sensed" by IF3 as being incorrect. However, unlike the noncanonical 30SIC complexes, which are discriminated against by IF3 during their formation, in this case IF3 does not prevent 30SIC formation but instead renders them nonproductive, probably imposing a spatial constraint upon the initiator tRNA to orient its $3^{\prime}$ acceptor end away from the P-site of the peptidyl transferase center.

\section{Temperature-dependent IF3 requirement for 705 dissociation}

The above experiments (Fig. 4) suggest that the increased level of IF3 during cold adaptation could be necessary to counteract an increased tendency of the ribosomal subunits to associate at low temperature. To verify this hypothesis, the effect of increasing levels of IF3 on the equilibrium $30 S+50 S \leftrightarrows 70 S$ was studied at low and high temperature. As seen in Figure 7A, at both temperatures the level of free subunits increases with increasing concentrations of IF3, but the amount of IF3 necessary to dissociate $50 \%$ of the $70 \mathrm{~S}$ ribosomes is two times higher at $15^{\circ} \mathrm{C}$ than at $37^{\circ} \mathrm{C}$. Since it has been shown that within the temperature range of the present experiment the $K_{\text {ass }}$ of the 30S-IF3 complex does not change (Grunberg-Manago et al. 1975), unlike
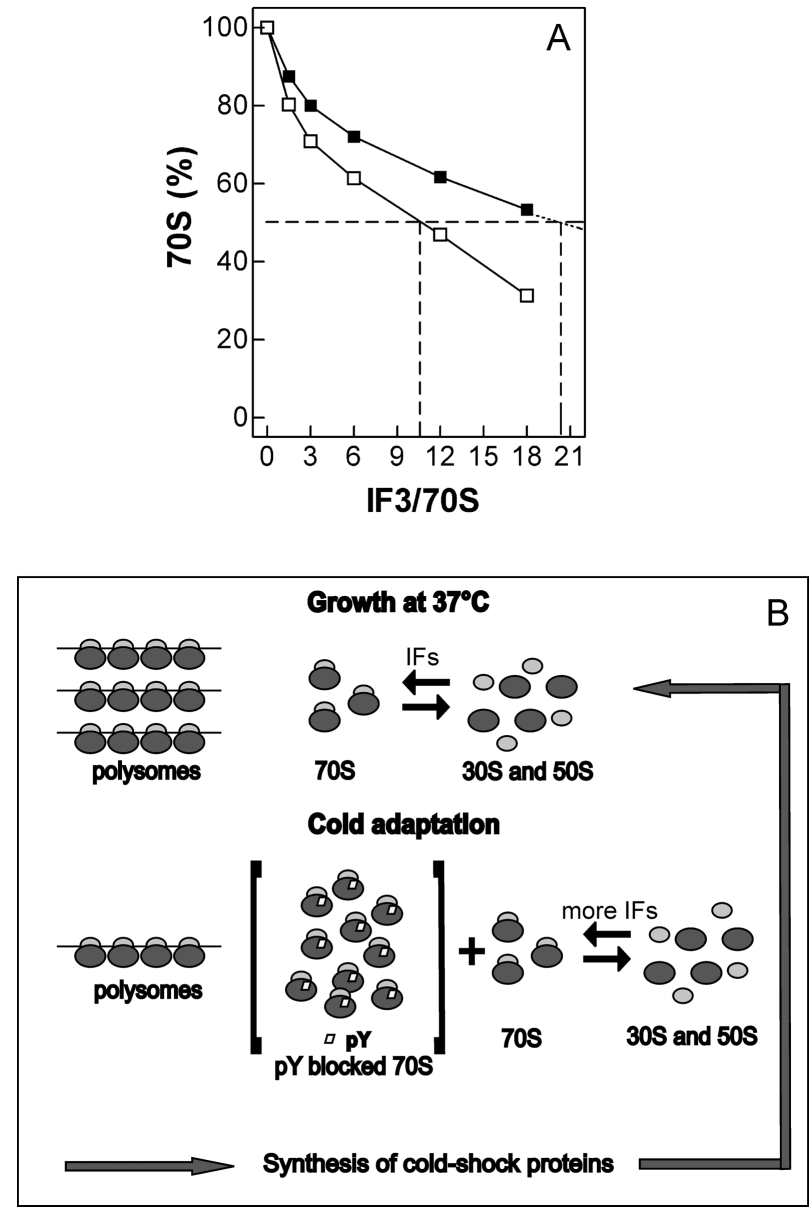

FIGURE 7. Enhanced IF3 requirement for 70S ribosomes dissociation at low temperature. (A) Effect of increasing amounts of IF3 on the dissociation of $70 \mathrm{~S}$ ribosomes at $37^{\circ} \mathrm{C}(\square)$ and $15^{\circ} \mathrm{C}(\boldsymbol{\square})$ in the presence of an IF1/ribosome ratio $=1.5$. Dissociation was quantitatively measured by sucrose density gradient centrifugation of "hybrid" $70 \mathrm{~S}$ ribosomes constituted by nonlabeled $50 \mathrm{~S}$ and $\left[{ }^{35} \mathrm{~S}\right]$-labeled $30 \mathrm{~S}$ as previously described (Petrelli et al. 2001). The dotted lines indicate the approximate amounts of IF3 required to obtain the dissociation of $50 \%$ of the $70 S$ monomers at the two temperatures. Further details are given in Materials and Methods. $(B)$ Schematic representation of the proposed role of IF3 in maintaining a sufficiently large pool of nonassociated $30 \mathrm{~S}$ and $50 \mathrm{~S}$ subunits during growth under optimal conditions of temperature and following the cold stress. See the text for explanations. 
that which characterizes 30S-50S association (Zitomer and Flaks 1972), it can be surmised that at the cold-shock temperature a larger amount of IF3 is needed to overcome an increased difficulty in shifting to the left the $30 \mathrm{~S}+50 \mathrm{~S} \leftrightarrows 70 \mathrm{~S}$ equilibrium.

In turn, this need, together with that of reducing the level of productive $70 S$ initiation complexes formed at low temperature with non-cold-shock mRNA, could explain the requirement for a transient increase of the IF3/70S ratio during the cold adaptation phase.

\section{DISCUSSION}

Previous studies have shown that one of the main mechanisms by which cold-stressed cells attain an increased expression of the cold-shock genes is by modification of the translational apparatus, which leads to the selective stimulation of cold-shock mRNA translation and to the repression of "non-cold-shock" mRNA translation at low temperature (Brandi et al. 1996; Goldenberg et al. 1997; Giuliodori et al. 2004). This "cold-shock translational bias" strongly depends upon initiation factor IF3, whose cellular level is increased more than threefold during the first few hours of cold adaptation at $10^{\circ} \mathrm{C}$ (Gualerzi et al. 2003; Giuliodori et al. 2004). This occurrence breaks the general rule that the initiation factors/ribosomes ratio is kept constant at 0.15-0.19 under all growth conditions (Howe and Hershey 1983). Thus, understanding the reasons and the functional consequences of this transient stoichiometric imbalance during cold adaptation represents a key step in understanding the mechanism responsible for genetic reprogramming after cold shock.

The present work demonstrates that the simultaneous cold-shock-induced de novo transcription and translation of infC and a virtual stop of ribosomal subunits assembly occurring immediately after the stress (as will be shown in a forthcoming article) are at the origin of the transient imbalance of the IF3/ribosome ratio.

The present data also indicate that the increase of the total infC transcript is due to the specific increase of the transcripts originating from $\mathrm{P}_{\mathrm{T}}$ and $\mathrm{P}_{\mathrm{I} 1}$ (Fig. 2B,C,D,F). Since the first promoter $\left(\mathrm{P}_{\mathrm{T}}\right)$ is located upstream from the thrS gene, it could be surmised that also the expression of threonyl-tRNA synthetase is increased upon cold shock, but this hypothesis must be experimentally verified. The second promoter $\left(\mathrm{P}_{\mathrm{I} 1}\right)$ is a less frequently used promoter located within the thrS coding region, $527 \mathrm{bp}$ upstream of $\mathrm{P}_{\mathrm{I} 2}$, which is the most commonly used promoter under all growth conditions (Liveris et al. 1991; Grunberg Manago 1996). Thus, as in the recently studied case of infA (Giangrossi et al. 2007), also in infC, cold stress seems to favor transcription from a less frequently used promoter to yield an mRNA with a longer $5^{\prime}$-UTR. In turn, it is likely that the longer $5^{\prime}$-UTR might increase the stability of the transcript and/or favor its translation in the cold.
Under normal growth conditions, the expression of infC is subject to translational auto-repression since IF3 discriminates against its own noncanonical AUU start codon (Brombach and Pon 1987; Butler et al. 1987; La Teana et al. 1993). In turn, translational repression of infCmRNA inhibits translation of the downstream rpmI and rplT transcripts that belong to the same transcriptional unit and are translationally coupled to infC. Thus, the increased level of IF3 during cold adaptation raises the questions of whether or not coordinated expression of IF3, L35, and L20 (Pediconi et al. 1995; Chiaruttini et al. 1997) is lost during cold adaptation and, possibly, what is the mechanism that allows the bypassing of this translational control.

Since IF3 was identified as being the main trans-acting factor capable of generating the cold-shock translational discrimination (Giuliodori et al. 2004), the central aim of this work was to identify which IF3 activity is essential during cold adaptation and to elucidate the molecular mechanism of the IF3-dependent translational bias.

Translation tests carried out in this study have demonstrated that at low temperature, IF3 activity is of fundamental importance in (1) increasing the velocity of fMet-tRNA binding to $30 \mathrm{~S}$ subunit programmed with cold-shock mRNA; (2) allowing the formation of a 70S initiation complex with cold-shock mRNA, thereby favoring their translation; and (3) inducing the formation of nonproductive $70 S$ initiation complexes containing non-cold-shock mRNA, thereby discriminating against translation of these mRNAs.

While some of these functions do not require the increased IF3/ribosome ratio, others, notably among these the formation of a 70SIC starting from a mixture of $30 \mathrm{~S}$ and $50 \mathrm{~S}$ subunits, are favored by its occurrence. It seems likely that the molecular basis of this activity resides in the subunits anti-association activity of IF3, which determines a net dissociation of $70 \mathrm{~S}$ monomers (Grunberg-Manago et al. 1975). The results obtained in experiments aimed at verifying this hypothesis have shown that an increased amount of IF3 is indeed required to avoid the situation in which the dynamic equilibrium $30 S+50 S \leftrightarrows 70 S$ might be shifted too much to the right as a result of the increased $K_{\text {ass }}$ of the two subunits caused by lowering the temperature (Zitomer and Flaks 1972). Thus, the stoichiometric imbalance of the IF3/ribosome ratio could play a fundamental role in compensating for the increased tendency of the subunits to associate at low temperature, thereby ensuring a sufficient pool of dissociated subunits capable of subsequently forming (1) a 30SIC, (2) a 70SIC, and eventually (3) entering elongation.

Our results have also shown that at low temperature only the initiation complexes formed in the presence of the cold-shock mRNA are fully productive, having the fMettRNA properly placed in the P-site. Instead, a large portion of the initiator tRNA bound in response to the non-coldshock mRNA is sequestered in a nonproductive complex through a novel "fidelity" function of IF3. While this IF3 
activity is consistent with the well-established role of this factor in assuring initiation fidelity (Gualerzi and Pon 1990), two characteristics of this newly discovered activity should be underlined. The first is that, unlike the other cases in which IF3 discriminates against "pseudo," "noncanonical," and "leaderless" initiation complexes (Gualerzi et al. 2001), in the present case, the factor does not promote the dissociation of the fMet-RNA from the 30 S subunit but instead pushes it into a nonproductive position. These differences suggest that the molecular mechanisms underlying these activities are likely different. The second characteristic is that the IF3 discrimination of complexes made in the cold with non-cold-shock mRNA reaches its maximum efficiency at stoichiometric levels of the factor that are similar to those attained by the factor during cold adaptation.

Overall, the present results suggest a model (Fig. 7B) that can rationalize the effect of the increased level of IF3 during cold shock and indicate a mechanism leading to the translational bias. Upon lowering the temperature, the amount of polysomes in the cell diminishes and the number of $70 \mathrm{~S}$ monomers correspondingly increases while the level of free subunits remains roughly unchanged (Uchida et al. 1970; Jones and Inouye 1996). A coldshock-induced protein ( $\mathrm{pY}$ ), whose likely function is that of "storing" part of the ribosomes as 70S monomers when the cell requires a reduced number of translating ribosomes (Maki et al. 2000; Agafonov et al. 2001), was found to bind between the P-site and the A-site of the $70 \mathrm{~S}$ monomers (Vila-Sanjurjo et al. 2004) and to prevent their dissociation. Thus, the cold-shock induction of pY would stabilize idle $70 S$ monomers deriving from polysome dissociation and sequester a large proportion of them in a functionally inactive state. However, the few pY-free and potentially active $70 \mathrm{~S}$ monomers would tend to remain stably associated at low temperature, thus reducing to an intolerably low level the pool of free subunits amenable to initiate cold-shock mRNA translation. Thus, to maintain an adequate pool of $30 \mathrm{~S}$ subunits able to bind cold-shock mRNAs and to initiate translation, the cell requires an increased level of IF3 to counteract the increased tendency of the ribosomal subunits to remain associated at low temperature.

IF3 increases both forward and back rates of the transition from " 30 S preinitiation complex" to " 30 S initiation complex," which leads to P-site decoding of fMet-tRNA on the 30 S subunit (Gualerzi et al. 2001) and can also induce repositioning of the mRNA from a "standby" to a "decoding" site of the 30 S subunit (La Teana et al. 1995). Thus, a plausible hypothesis to explain the biased stimulation of fMet-tRNA binding is that the structure of the cold-shock mRNA (or perhaps just of its long $5^{\prime}$-UTR) is endowed with some particular feature that makes the above mentioned transition and/or shift possible at low temperature, albeit strongly IF3 dependent. On the other hand, an unfavorable structure of non-cold-shock mRNA could hinder the above mentioned transitions so as to make them less efficient, even at $37^{\circ} \mathrm{C}$ and essentially IF3 independent. However, at low temperature IF3 would "distort" the position of the 30S-bound fMet-tRNA so as to eventually direct it into a nonproductive $70 \mathrm{~S}$ initiation complex (Fig. 6).

Overall, these results seem to highlight the importance of an interplay between mRNA structure and IF3 function that determines the efficient and productive accommodation of the ribosomal ligands at low temperature. The observation (not shown) that after a long incubation time cspAmRNA-directed binding of fMet-tRNA can reach appreciably high levels even in the absence of IF3, and that these are comparable to those attained, after similar incubation times, with cspDmRNA in the presence or absence of IF3 is consistent with this premise and underlie the need for slow (in the absence of IF3) and mRNA structure-dependent spatial adjustments of the ligands on the ribosomal surface.

\section{MATERIALS AND METHODS}

\section{Buffers and general preparations}

Buffer A: $20 \mathrm{mM}$ Tris- $\mathrm{HCl}\left(\mathrm{pH}\right.$ 7.7), $80 \mathrm{mM} \mathrm{NH}_{4} \mathrm{Cl}, 7 \mathrm{mM} \mathrm{Mg}$ acetate, and $1 \mathrm{mM}$ DTT. Escherichia coli MRE600 30S and 50S ribosomal subunits and purified initiation factors IF1, IF2, and IF3 were prepared as described previously (Pawlik et al. 1981; Ohsawa and Gualerzi 1983); tRNA $_{\mathrm{fMet}}$ was kindly provided by Dr. S. Kirillov (Gatchina) and aminoacylated, formylated and purified as described (Rodnina et al. 1994; Brandi et al. 2004). In vitro transcribed mRNAs and E. coli MRE600 S30 extracts were produced and purified as described (Giuliodori et al. 2004).

\section{Cold-shock induction}

Cultures of E. coli MRE600 growing in $\mathrm{LB}$ at $37^{\circ} \mathrm{C}$ were subjected to temperature downshift (to $10^{\circ} \mathrm{C}$ ) upon reaching $\mathrm{A}_{600}=0.3,1.0$ or 1.2 as specified, and maintained at $10^{\circ} \mathrm{C}$ for the times indicated in each experiment.

\section{Northern blot analysis}

The steady-state levels of the infC transcripts were determined by Northern blot analysis of the total RNA as described (Brandi et al. 1996).

\section{Primer extension analysis}

Primer extension analyses were performed essentially as described (Giangrossi et al. 2007). The oligonucleotides \#G199 5'-ACGGG ATGTTGTTTTCTTCCAG-3', \#G200 5'-CCATGCTTCCCAGGT CTTTA-3' , and \#G233 5' -TATTAACAGTTCATTGCGAAACC-3' were used as primers for the identification of the $\mathrm{P}_{I 1}, \mathrm{P}_{I 2}$, and $\mathrm{P}_{\mathrm{T}}$ transcripts, respectively. The reaction products were loaded on a $7 \%$ polyacrylamide- $8 \mathrm{M}$ urea gel and electrophoresed in parallel with a dideoxy chain termination sequencing reaction carried out using the same oligonucleotide primers. 


\section{De novo synthesis of IF3 after cold shock}

De novo synthesis of IF3 after cold shock was measured by pulse-chase experiments followed by immunoprecipitation, electrophoretic separation, and quantification by molecular imager essentially as described (Brandi et al. 1996; Giangrossi et al. 2002).

\section{In vitro translational tests}

In vitro translation experiments (Giuliodori et al. 2004) and quantification of IF3-induced dissociation of $70 \mathrm{~S}$ monomers (Petrelli et al. 2001) were performed essentially as described.

\section{$30 S$ initiation complex (30SIC) and $70 S$ initiation complex (70SIC) formation}

A typical reaction mixture contained, in $30 \mu \mathrm{L}$ Buffer $\mathrm{A}, 0.5 \mathrm{mM}$ GTP, $0.5 \mu \mathrm{M} \mathrm{f}\left[{ }^{35} \mathrm{~S}\right]$ Met-tRNA, $0.5 \mu \mathrm{M}$ IF1 and IF2, $1 \mu \mathrm{M}$ of either $\operatorname{cspAmRNA}$ or $\operatorname{cspDmRNA}, 0.5 \mu \mathrm{M} 30 \mathrm{~S}$ ribosomal subunits with or without $0.5 \mu \mathrm{M}$ of $50 \mathrm{~S}$ subunits as indicated, and the specified amounts of IF3. After $30 \mathrm{~min}$ incubation at either $37^{\circ} \mathrm{C}$ or $15^{\circ} \mathrm{C}$ the amount of $\mathrm{f}\left[{ }^{35} \mathrm{~S}\right]$ Met-tRNA bound in the 30SIC was determined by nitrocellulose filtration.

\section{Kinetics of 30SIC formation}

The experiments were performed essentially as described (Milon et al. 2006) with minor modifications. In a typical experiment syringe A was filled with Buffer A containing $1 \mathrm{mM}$ GTP, $1 \mu \mathrm{M}$ $30 \mathrm{~S}$ ribosomal subunit, $1 \mu \mathrm{M}$ IF1, $1 \mu \mathrm{M}$ IF2, and different amounts of IF3 as indicated in the figures, while syringe B contained, in the same buffer, $1 \mu \mathrm{M} \mathrm{f}\left[{ }^{35} \mathrm{~S}\right]$ Met-tRNA and $2 \mu \mathrm{M} \operatorname{csp} A$ or $\operatorname{cspDmRNA}$. After keeping the solutions for $10 \mathrm{~min}$ at the programmed temperature $\left(37^{\circ}\right.$ or $\left.15^{\circ} \mathrm{C}\right), 30 \mu \mathrm{L}$ of each solution were rapidly mixed and allowed to age for the indicated times; the reactions were then stopped by rapid dilution and filtration (Milon et al. 2006) and the amount of $\mathrm{f}\left[{ }^{35} \mathrm{~S}\right]$ Met-tRNA bound in the $30 \mathrm{~S}$ initiation complex present on each filter measured by liquid scintillation counting.

\section{Puromycin reaction}

The 30SIC were prepared in reaction mixtures containing (in $1 \mathrm{~mL}$ Buffer A) $0.5 \mathrm{mM}$ GTP, $0.5 \mathrm{nmol} \mathrm{f}\left[{ }^{35} \mathrm{~S}\right]$ Met-tRNA, $1 \mathrm{nmol}$ of $\operatorname{csp} A$ mRNA or $\operatorname{csp} D$ mRNA, $0.5 \mathrm{nmol}$ each of $30 \mathrm{~S}$ subunit, IF1, and IF2. The amounts of IF3 present in each reaction are indicated in the appropriate figure legends. After $30 \mathrm{~min}$ incubation at $37^{\circ} \mathrm{C}$ or $15^{\circ} \mathrm{C}, 50-\mu \mathrm{L}$ aliquots were withdrawn from each mixture to determine the amount of 30 SIC-bound $\mathrm{f}\left[{ }^{35} \mathrm{~S}\right]$ Met-tRNA by nitrocellulose filtration. $\mathrm{f}\left[{ }^{35} \mathrm{~S}\right]$ Met-puromycin formation was started by adding $50 \mu \mathrm{L}$ aliquots of a mixture containing $50 \mathrm{~S}$ ribosomal subunits $(30 \mathrm{pmol})$ and puromycin $(2 \mathrm{mM})$ in Buffer A to $50-\mu \mathrm{L}$ aliquots of the reaction mixture containing the specified type of 30SIC. The samples were then incubated for the indicated times at either $37^{\circ} \mathrm{C}$ or $15^{\circ} \mathrm{C}$ and the reactions stopped by addition of $500 \mu \mathrm{L}$ of $1 \mathrm{M}\left(\mathrm{NH}_{4}\right) \mathrm{HCO}_{3}(\mathrm{pH} 9.0)$. The $\mathrm{f}\left[{ }^{35} \mathrm{~S}\right]$ Met-puromycin formed was extracted with $1 \mathrm{~mL}$ of ethyl acetate and the radioactivity present in the ethyl acetate phase was determined by liquid scintillation counting.

\section{ACKNOWLEDGMENTS}

The costs of this investigation were partially supported by Italian MIUR grants (FIRB 2001, PRIN 2003, and 2005 to C.L.P. and PRIN 2005 to C.O.G.).

Received January 4, 2007; accepted May 4, 2007.

\section{REFERENCES}

Agafonov, D.E., Kolb, V.A., and Spirin, A.S. 2001. Ribosomeassociated protein that inhibits translation at the aminoacyl-tRNA binding stage. EMBO Rep. 2: 399-402.

Boelens, R. and Gualerzi, C.O. 2002. Structure and function of bacterial initiation factors. Curr. Protein Pept. Sci. 3: 107-119.

Brandi, A., Pietroni, P., Gualerzi, C.O., and Pon, C.L. 1996. Posttranscriptional regulation of CspA expression in Escherichia coli. Mol. Microbiol. 19: 231-240.

Brandi, A., Spurio, R., Gualerzi, C.O., and Pon, C.L. 1999. Massive presence of the Escherichia coli "major cold-shock protein" CspA under nonstress conditions. EMBO J. 18: 1653-1659.

Brandi, L., Marzi, S., Fabbretti, A., Fleischer, C., Hill, W., Gualerzi, C.O., and Lodmell, S. 2004. The translation initiation functions of IF2: Targets for thiostrepton inhibition. J. Mol. Biol. 335: 881-894.

Brombach, M. and Pon, C.L. 1987. The unusual translational initiation codon AUU limits the expression of the infC (initiation factor IF3) gene of Escherichia coli. Mol. Gen. Genet. 208: 94-100.

Butler, J.S., Springer, M., and Grunberg-Manago, M. 1987. AUU-toAUG mutation in the initiator codon of the translation initiation factor IF3 abolishes translational autocontrol of its own gene (infC) in vivo. Proc. Natl. Acad. Sci. 84: 4022-4025.

Chiaruttini, C., Milet, M., and Springer, M. 1997. Translational coupling by modulation of feedback repression in the IF3 operon of Escherichia coli. Proc. Natl. Acad. Sci. 94: 9208-9213.

Giangrossi, M., Exley, R.M., Le Hegarat, F., and Pon, C.L. 2001. Different in vivo localization of the Escherichia coli proteins CspD and CspA. FEMS Microbiol. Lett. 202: 171-176.

Giangrossi, M., Giuliodori, A.M., Gualerzi, C.O., and Pon, C.L. 2002. Selective expression of the $\beta$-subunit of nucleoid-associated protein HU during cold-shock in Escherichia coli. Mol. Microbiol. 44: 205-216.

Giangrossi, M., Brandi, A., Giuliodori, A.M., Gualerzi, C.O., and Pon, C.L. 2007. Cold-shock-induced de novo transcription and translation of infA and role of IF1 during cold adaptation. Mol. Microbiol. 64: 807-821.

Giuliodori, A.M., Brandi, A., Gualerzi, C.O., and Pon, C.L. 2004. Preferential translation of cold-shock mRNAs during cold adaptation. RNA 10: 265-276.

Goldenberg, D., Azar, I., Oppenheim, A.B., Brandi, A., Pon, C.L., and Gualerzi, C.O. 1997. Role of Escherichia coli $\operatorname{cspA}$ promoter sequences and adaptation of translational apparatus in the coldshock response. Mol. Gen. Genet. 256: 282-290.

Goldstein, J., Pollitt, N.S., and Inouye, M. 1990. Major cold-shock protein of Escherichia coli. Proc. Natl. Acad. Sci. 87: 283-287.

Grunberg-Manago, M. 1996. Regulation of the expression of aminoacyltRNA synthetases and translational factors. In Escherichia coli and Salmonella (ed. F.C. Neidhardt), pp. 1432-1457. ASM Press, Washington, DC.

Grunberg-Manago, M., Dessen, P., Pantaloni, D., GodefroyColburn, T., Wolfe, A.D., and Dondon, J. 1975. Light-scattering studies showing the effect of initiation factors on the reversible dissociation of Escherichia coli ribosomes. J. Mol. Biol. 94: 461-478.

Gualerzi, C.O. and Pon, C.L. 1990. Initiation of mRNA translation in prokaryotes. Biochemistry 29: 5881-5889.

Gualerzi, C.O., Brandi, L., Caserta, E., Garofalo, C., Lammi, M., La Teana, A., Petrelli, D., Spurio, R., Tomsic, J., and Pon, C.L. 2001. 
Role of the initiation factors in the early events of mRNA translation in bacteria. Cold Spring Harb. Symp. Quant. Biol. 66: 363-376.

Gualerzi, C.O., Giuliodori, A.M., and Pon, C.L. 2003. Transcriptional and post-transcriptional control of cold-shock genes. J. Mol. Biol. 331: $527-539$.

Howe, J.G. and Hershey, J.W. 1983. Initiation factor and ribosome levels are coordinately controlled in Escherichia coli growing at different rates. J. Biol. Chem. 258: 1954-1959.

Jones, P.G. and Inouye, M. 1996. RbfA, a 30 S ribosomal binding factor, is a cold-shock protein whose absence triggers the coldshock response. Mol. Microbiol. 21: 1207-1218.

La Teana, A., Pon, C.L., and Gualerzi, C.O. 1993. Translation of mRNAs with degenerate initiation triplet AUU displays high IF2 dependence and is subject to IF3 repression. Proc. Natl. Acad. Sci. 90: 4161-4165.

La Teana, A., Gualerzi, C.O., and Brimacombe, R. 1995. From standby to decoding site. Adjustment of the mRNA on the $30 \mathrm{~S}$ ribosomal subunit under the influence of the initiation factors. RNA 1: 772-782.

Laursen, B.S., Sørensen, H.P., Mortensen, K.K., and SperlingPetersen, H.U. 2005. Initiation of protein synthesis in bacteria. Microbiol. Mol. Biol. Rev. 69: 101-123.

Lesage, P., Truong, H.N., Graffe, M., Dondon, J., and Springer, M. 1990. Translated translational operator in Escherichia coli. Autoregulation in the infC-rpmI-rplT operon. J. Mol. Biol. 213: 465-475.

Liveris, D., Klotsky, R.A., and Schwartz, I. 1991. Growth rate regulation of translation initiation factor IF3 biosynthesis in Escherichia coli. J. Bacteriol. 173: 3888-3893.

Maki, Y., Yoshida, H., and Wada, A. 2000. Two proteins, YfiA and $\mathrm{YhbH}$, associated with resting ribosomes in stationary phase Escherichia coli. Genes Cells 5: 965-974.

Milon, P., Tischenko, E., Tomsic, J., Caserta, E., Folkers, G., La Teana, A., Rodnina, M.V., Pon, C.L., Boelens, R., and Gualerzi, C.O. 2006. The nucleotide-binding site of bacterial translation initiation factor 2 (IF2) as a metabolic sensor. Proc. Natl. Acad. Sci. 103: 13962-13967.

Ohsawa, H. and Gualerzi, C. 1983. Chemical modification in situ of Escherichia coli $30 \mathrm{~S}$ ribosomal proteins by the site-specific reagent pyridoxal phosphate: Inactivation of the aminoacyl-tRNA and mRNA binding sites. J. Biol. Chem. 258: 150-156.

Olsson, C.L., Graffe, M., Springer, M., and Hershey, J.W. 1996. Physiological effects of translation initiation factor IF3 and ribosomal protein L20 limitation in Escherichia coli. Mol. Gen. Genet. 250: 705-714.

Pawlik, R.T., Littlechild, J., Pon, C.L., and Gualerzi, C. 1981. Purification and properties of E. coli initiation factors. Biochem. Int. 2: $421-428$.

Pediconi, D., Spurio, R., La Teana, A., Jemiolo, D., Gualerzi, C.O., and Pon, C.L. 1995. Translational regulation of infC operon in Bacillus stearothermophilus. Biochem. Cell. Biol. 73: 1071-1078.

Petrelli, D., La Teana, A., Galofaro, C., Spurio, R., Pon, C.L., and Gualerzi, C.O. 2001. Translation initiation factor IF3: Two domains, five functions one mechanism. EMBO J. 20: 4560-4569.

Rodnina, M.V., Semenkov, Y.P., and Wintermeyer, W. 1994. Purification of fMet-tRNA(fMet) by fast protein liquid chromatography. Anal. Biochem. 219: 380-381.

Uchida, T., Abe, M., Matsuo, K., and Yoneda, M. 1970. Amounts of free $70 S$ ribosomes and ribosomal subunits found in Escherichia coli at various temperatures. Biochem. Biophys. Res. Commun. 41: 1048-1054.

Vila-Sanjurjo, A., Schuwirth, B.S., Hau, C.W., and Cate, J.H. 2004. Structural basis for the control of translation initiation during stress. Nat. Struct. Mol. Biol. 11: 1054-1059.

Wertheimer, S.J., Klotsky, R.A., and Schwartz, I. 1988. Transcriptional patterns for the thrS-infC-rplT operon of Escherichia coli. Gene 63: 309-320.

Yamanaka, K. and Inouye, M. 1997. Growth-phase-dependent expression of $\operatorname{cspD}$, encoding a member of the CspA family in Escherichia coli. J. Bacteriol. 179: 5126-5130.

Yamanaka, K., Fang, L., and Inouye, M. 1998. The CspA family in Escherichia coli: Multiple gene duplication for stress adaptation. Mol. Microbiol. 27: 247-255.

Zitomer, R.S. and Flaks, J.G. 1972. Magnesium dependence and equilibrium of the Escherichia coli ribosomal subunit association. J. Mol. Biol. 71: 263-279. 

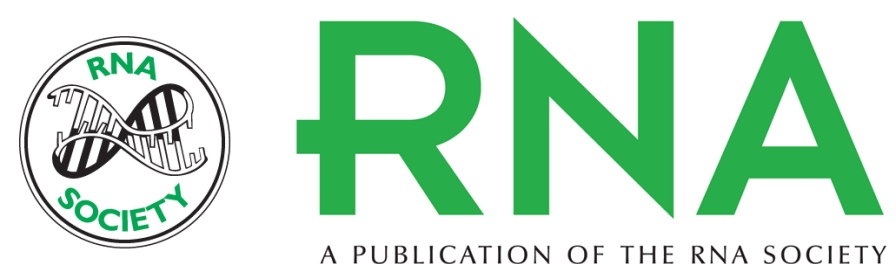

A PUBLICATION OF THE RNA SOCIETY

\section{Cold-stress-induced de novo expression of infC and role of IF3 in cold-shock translational bias}

Anna Maria Giuliodori, Anna Brandi, Mara Giangrossi, et al.

RNA 2007 13: 1355-1365 originally published online June 25, 2007

Access the most recent version at doi:10.1261/rna.455607

$\begin{array}{ll}\text { References } & \begin{array}{l}\text { This article cites } 39 \text { articles, } 15 \text { of which can be accessed free at: } \\ \text { http://rnajournal.cshlp.org/content/13/8/1355.full.html\#ref-list-1 }\end{array}\end{array}$

License

Email Alerting Receive free email alerts when new articles cite this article - sign up in the box at the Service top right corner of the article or click here. 